\title{
Relationship of Biometrical Aspect of Turritellidae with Geochronological Aspect in West Java
}

\author{
Hita Pandita', Yahdi Zaim², ${ }^{2}$ Swan $^{2}$, Yan Rizal ${ }^{2}$ \\ ${ }^{1}$ Department of Geology, Institute of Technology Bandung, Sekolah Tinggi Teknologi Nasional, Yogyakarta, Indonesia \\ ${ }^{2}$ Department of Geology, Institute of Technology, Bandung, Indonesia \\ Email: hita@indo.net.id
}

Received February 26, 2013; revised March 28, 2013; accepted April 25, 2013

Copyright (C) 2013 Hita Pandita et al. This is an open access article distributed under the Creative Commons Attribution License, which permits unrestricted use, distribution, and reproduction in any medium, provided the original work is properly cited.

\begin{abstract}
Mollusk paleontology research in Indonesia so far has not been widely utilized in various kinds of applications, especially in the geology. Although mollusk in Java is very rich, the study of correlation between mollusk appearances with geological condition is rare. This study aimed to determine Turritellidae base on morphological observations (qualitative) and quantitative (biometric method). The ultimate goal is to find out the relationship between of biometrical aspect of Turritellidae with geological development especially of chronological conditions. Stratigraphic analysis and sampling have done at five location of field survey. Site selection was based on the type locality of mollusk biostratigraphic unit arrange by Martin (1919) [1] and Oostingh (1938) [2]. The scattered analysis shows two large distribution of consistent groups based on shell size and geochronological aspect. Biometrical aspect of Turritellidae is reflection of the chronological aspect in West Java. Small size was appearance in Upper Miocene to Lower Pliocene and large shell in Pliocene to Pleistocene.
\end{abstract}

Keywords: Biometry; Turritellidae; West Java; Mollusk; Paleontology

\section{Introduction}

Paleontology research on mollusk has not really been well developed in Indonesia so far. Mollusc paleontology research have been initiated by Jenkins (1863) [3] and continued by Martin (1919) [1], Oostingh (1938) [2], and other that deal with taxonomy and biostratigraphy. Martin (1919) [1] and Oostingh (1938) [2] introduced molluscan biostratigraphy in Java based on assemblages and index fossil of mollusc. The research then continued by several researchers such as Pozzobon (1997) [4], Aswan (1997) [5], Shuto (1974) [6], Kase et al. (2008) [7], and others. However most of studies focused on aspects of taxonomy and less at the application of geology. Occurrences of mollusc fossils have not been optimally utilized in various of geological applications.

Therefore, an assessment of the usefulness of fossil mollusks in various aspects of geology needs to done. One aspect is important to know the relationship of shell growth Turritellidae with the geological aspects.

The aim of this study is to determine the Turritellidae approached by qualitative and quantitative methods and the ultimate goal is to find out the relationship of the occurrence of Turritellidae with geological development especially of chronological in the study area.

\section{Location and Method}

The study areas are located at five locations in West Java area (Figure 1). There are Cilanang Rivers (Mt. Halu), Cisanggarong Rivers (Menengten/Waled Village), Pasir Ipis (Cirebon), Cijarian River (Pelabuhan Ratu) and Leuwimeteng (Bojong). The selection of these areas is based on the type locality of biostratigraphic unit as compiled by Martin (1919) [1] and Oostingh (1938) [2].

During field investigations conducted rock sampling, stratigraphic profiling, and fossils sampling. Some rocks and 49 Turritellidae had been collected for five locations. Five stratigraphic profiling from five sites has been done during field study.

Laboratory analysis devided into molusks fossils identify and age determine. Mollusc identify done by morphological observation and biometrical measurement of mollusc shell. Age determine based on micropaleontology data and regional stratigraphy.

\section{Stratigraphy}

The five sites of study area are representative of some of 


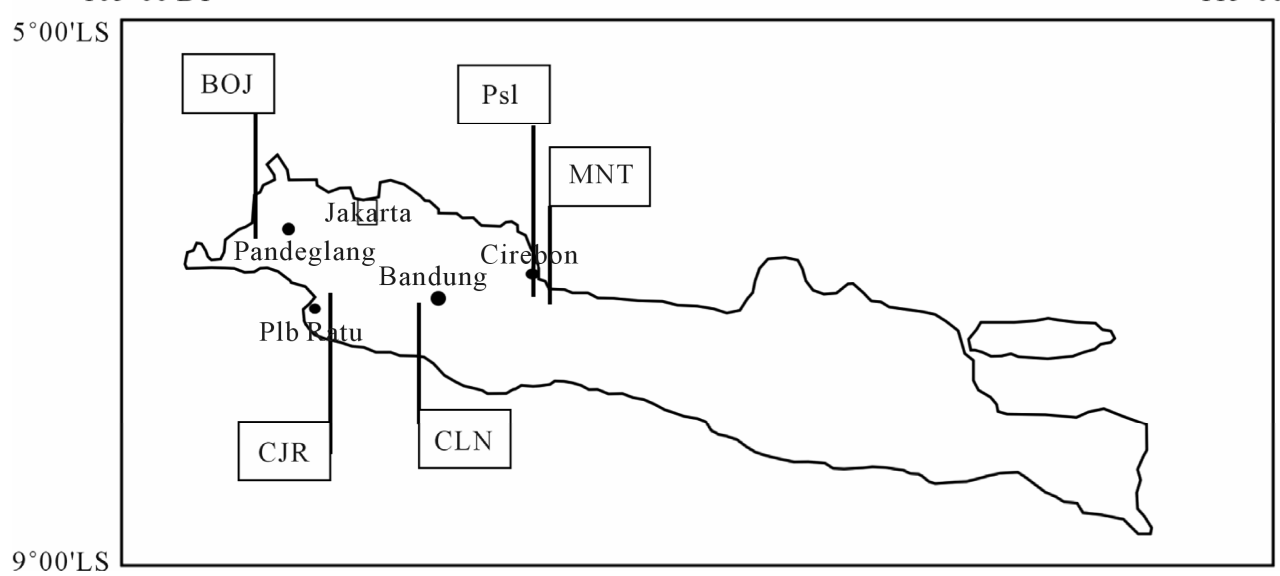

Figure 1. Sampling sites of fossil molluscs family of Turritellidae in West Java. Description of location, CLN: Cilanang; MNT: Menengten; PsI: Pasir Ipis; CJR: Cijarian; BOJ: Bojong.

the biostratigraphic units compiled by Martin (1919) [1] and Oostingh (1938) [2]. Cijarian site for the Tjiodeng stages, Cilanang site for the Tjilanang stages, Menengten and Pasir Ipis sites for Kaliwangu formation, and Bojong for the Bantamian stage (Table 1).

According to regional stratigraphic two location are representatif age in Upper Miocene-Lower Pliocene there are CLN01 and CJR02B. Three location are represent atif age in Pliocene-Pleistocene there are MNT13, PsI, and BOJ03.

\section{Fossil Identification}

Taxonomical characters of Turritellidae have been developed by several authors. Merriam (1941) [9] proposed three main parameters for identification: 1) the outer lip trace, 2) the ontogeny of primary spiral and 3) protoconch. These parameters have been accepted by some authors such as Marwick (1957) [10] and Kotaka (1959) [11] with some detail improvements. Shuto (1969) [12] has accepted also, but he added other parameters with respect to biometry.

In Turritellidae the morphological observation comprises of the number of spiral ribs, sculpture, protoconch shape and teleconch. Biometric measurement including of the number of whorls, shell length (L), maximum width of the last whorl $\left(\mathrm{W}_{\mathrm{ang}}\right)$, wide sutures in the last whorl ( $\left.\mathrm{W}_{\text {sut }}\right)$, and the apex angle $(\alpha)$ (Figure 2). Additionally, in some taxa has been also measured the width of the whorl that changes the shape of the first whorl $\left(\mathrm{W}_{\mathrm{n}}\right)$. Fifty specimens have been taken from the study area as shown in Tables 2 to $\mathbf{6}$. The selection of five species was based on their morphological resemblance of monocarinate. These specimens are representing five species: Turritella sp (MNT13), T. bantamensis (BOJ 3), T. simplex (CLN01A), T. djadjariensis (PsI), and T. javana (CJR02).

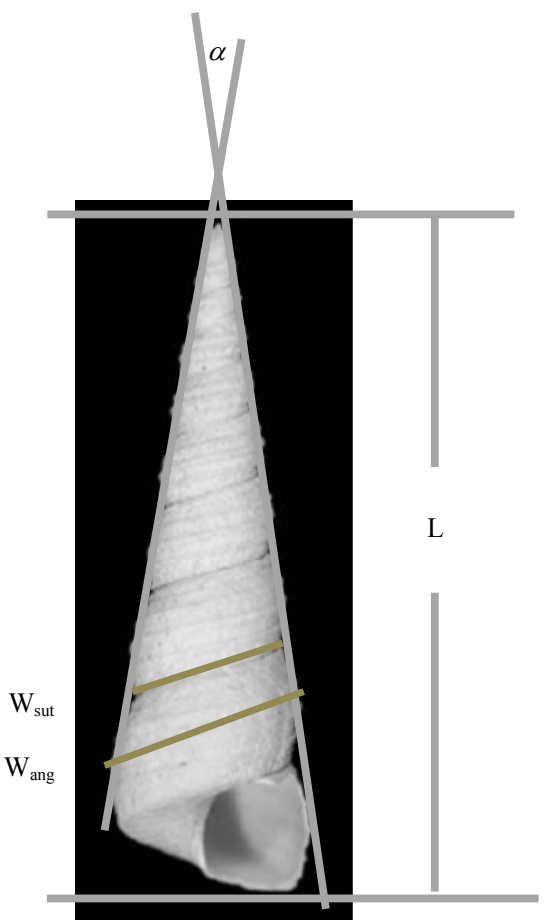

Figure 2. Parameter measured in Turritellidae shell.

\section{Analysis}

Biometric data of Turritellidae have been analyzed with statistical method. The analysis is carried out on four parameters: 1) the ratio of shell length with whorl number, 2) the ratio of $\mathrm{W}_{\text {ang }}$ with $\mathrm{W}_{\text {sut }}, 3$ ) the ratio of shell length (L) with $\mathrm{W}_{\text {ang, }}$, and 4) the ratio of shell length with $\mathrm{W}_{\text {sut }}$. Fixation these parameter is based on assumption that organism will always have the consistency of growth, when one parameter was going up it should be follow by the other ones. The ratio of shell length with whorl number has been proposed by Aswan (1997) [5], but the other 
Table 1. Regional stratigraphy of mollusk sample sites in West Java (compilation from Martodjojo, 2003 [8], Oostingh, 1938 [2] and Martin 1919 [1]).

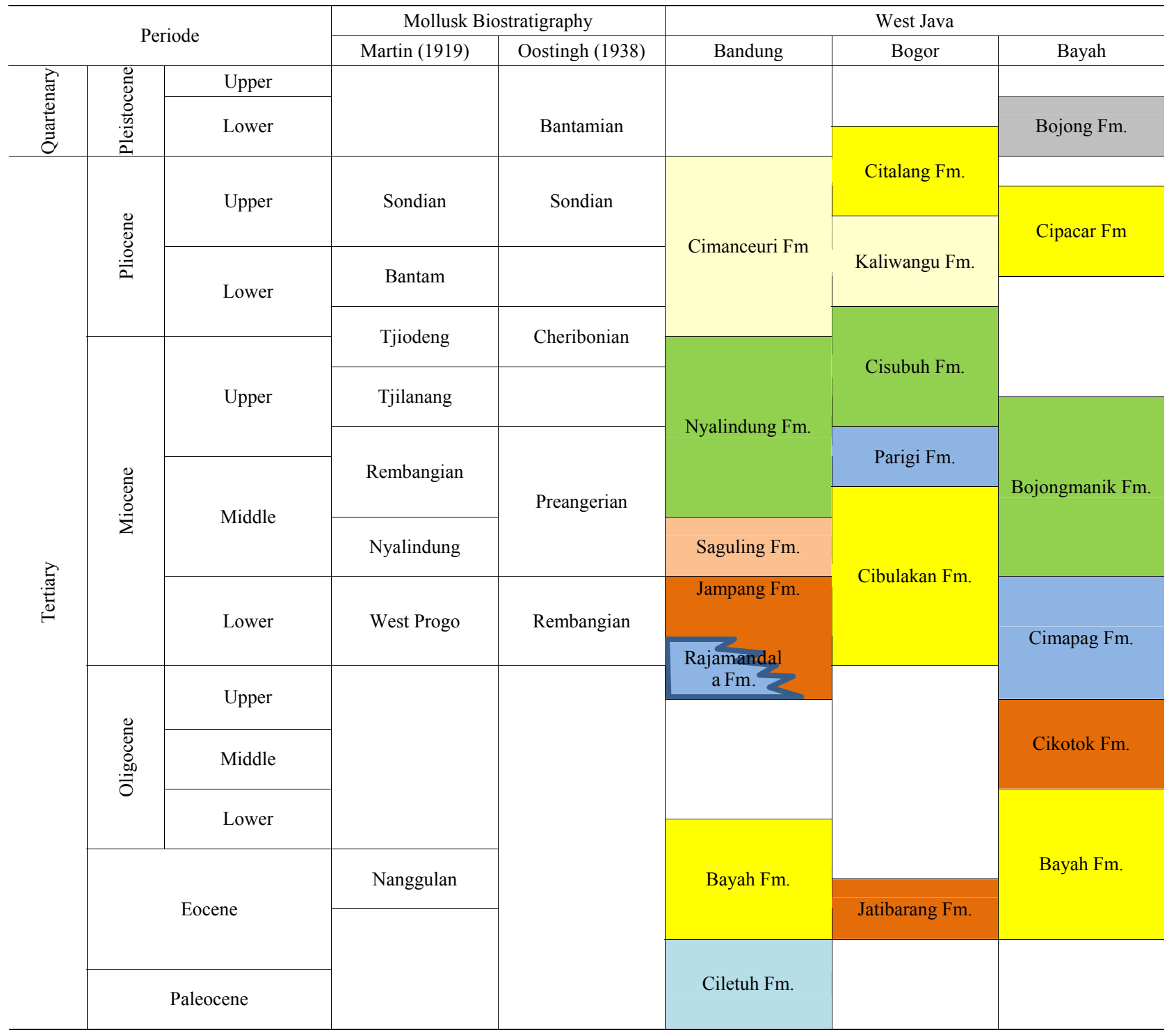

ratio are proposed in this study.

Based on shell length, Kotaka (1959) [11] devided shell into two group, there are small shell if measurement less than $60 \mathrm{~mm}$, and large shell if more than $60 \mathrm{~mm}$. Result of the measurement from samples could be devided into two group, there are small shell represented samples code CLN-01A and CJR02B and large shell represented samples code MNT13, PsI and BOJ03.

\subsection{Ratio of Shell Length (L): Whorl Number}

This ratio is based on the results of measuring the shell length and the total whorl number. Aswan (1997) [5] proposed this parameter and proved that added of shell lenght is correlated with added of whorl number. In some species will show a different pattern on linear regression.
The measurement of specimens shows that MNT13 and CJR02B have a wide distribution, while the other sample have a narrow distribution. Approach with a cluster analysis it can be grouped in two clusters. Cluster A represents the shell in long less than $60 \mathrm{~cm}$, included in this group are CLN01A and CJR02B (Figure 3). Cluster $\mathrm{B}$ represents longer shells size are included in this group MNT13, Pasir Ipis and BOJ03.

\subsection{Ratio of Shell Length (L): $W_{\text {ang }}$}

This parameter is based on the ratio of the shell length with a maximum wide of last whorl. Although many paleontologists have measured the shell length and maximum wide of last whorl, they never used this ratio as parameter to identify. The assumption of this parameter 
Table 2. The biometric measurements of Turritella sp. from Meningten area.

\begin{tabular}{|c|c|c|c|c|c|c|c|c|c|}
\hline \multirow{3}{*}{$\begin{array}{c}\text { Code } \\
\text { Species } \\
\text { Location }\end{array}$} & \multicolumn{9}{|l|}{ MNT 13} \\
\hline & \multicolumn{9}{|c|}{ Turritella sp. } \\
\hline & \multicolumn{9}{|c|}{ Waled Village, Cisanggarong river (Meningten Valley) } \\
\hline No. Spec & $\mathrm{L}_{(\mathrm{mm})}$ & $\mathrm{W}_{\text {ang }}$ & $\mathrm{W}_{\text {sut }}$ & $\mathrm{W}_{\mathrm{w} 9}$ & $\alpha\left(^{\circ}\right)$ & Whorl Number & $\mathrm{W}_{\mathrm{ang}}: \mathrm{L}$ & $\mathrm{W}_{\text {sut }}: \mathrm{L}$ & $\mathrm{W}_{\text {sut }}: \mathrm{W}_{\text {ang }}$ \\
\hline $1 \mathrm{~B}$ & 68.80 & 25.00 & 15.85 & 13.00 & 12.50 & 12 & 0.3633721 & 0.2303779 & 0.634 \\
\hline 2B & 73.30 & 28.80 & 16.60 & 14.30 & 11.00 & 12 & 0.3929059 & 0.2264666 & 0.5763889 \\
\hline $3 \mathrm{~B}$ & 63.85 & 20.45 & 15.00 & 12.90 & 12.50 & 12 & 0.3202819 & 0.2349256 & 0.7334963 \\
\hline $4 \mathrm{~B}$ & 71.90 & 29.40 & 16.50 & 13.35 & 15.00 & 12 & 0.4089013 & 0.2294854 & 0.5612245 \\
\hline $5 B$ & 72.60 & 28.55 & 16.45 & 12.95 & 14.00 & 12 & 0.3932507 & 0.226584 & 0.5761821 \\
\hline $6 \mathrm{~B}$ & 90.90 & 26.75 & 18.30 & 14.75 & 11.00 & 13 & 0.2942794 & 0.201320 & 0.6841121 \\
\hline $1 \mathrm{Y}$ & 95.70 & 28.30 & 22.50 & 14.00 & 15.00 & 13 & 0.2957158 & 0.235110 & 0.795053 \\
\hline $2 \mathrm{Y}$ & 85.30 & 32.50 & 19.10 & 15.50 & 13.00 & 13 & 0.3810082 & 0.2239156 & 0.5876923 \\
\hline $3 Y$ & 97.20 & 30.30 & 20.10 & 16.10 & 13.50 & 12 & 0.3117284 & 0.2067901 & 0.6633663 \\
\hline $4 Y$ & 64.70 & 22.60 & 15.40 & & & 10 & 0.3493045 & 0.2380216 & 0.6814159 \\
\hline $5 \mathrm{Y}$ & 89.00 & 27.40 & 18.30 & 12.50 & 12.50 & 14 & 0.3078652 & 0.205618 & 0.6678832 \\
\hline $6 \mathrm{Y}$ & 63.90 & 22.80 & 16.20 & 13.40 & 15.00 & 12 & 0.3568075 & 0.2535211 & 0.7105263 \\
\hline $7 Y$ & 82.40 & 26.45 & 18.50 & 13.20 & 13.00 & 13 & 0.3209951 & 0.2245146 & 0.6994329 \\
\hline $8 \mathrm{Y}$ & 77.00 & 31.50 & 18.30 & 14.10 & 14.00 & 13 & 0.4090909 & 0.2376623 & 0.5809524 \\
\hline
\end{tabular}

Table 3. The biometric measurements of Turritella bantamensis from Bojong area.

\begin{tabular}{|c|c|c|c|c|c|c|c|c|c|}
\hline Code & BOJ3 & & & & & & & & \\
\hline Species & Zaria bant & & & & & & & & \\
\hline Location & Mekarjaya & & & & & & & & \\
\hline No. Spec & $\mathrm{L}_{(\mathrm{mm})}$ & $\mathrm{W}_{\text {ang }}$ & $\mathrm{W}_{\text {sut }}$ & $\mathrm{W}_{\mathrm{w} 7}$ & $\alpha\left(^{\circ}\right)$ & Whorl Number & $\mathrm{W}_{\text {ang }}: \mathrm{L}$ & $\mathrm{W}_{\text {sut }}: \mathrm{L}$ & $\mathrm{W}_{\text {sut }}: \mathrm{W}_{\text {ang }}$ \\
\hline BOJ3-1B & 94.60 & 20.50 & 16.00 & 7.75 & 10.00 & 13.00 & 0.216702 & 0.169133 & 0.780488 \\
\hline ВOJ3-2B & 95.00 & 22.30 & 16.95 & 7.00 & 13.00 & 13.00 & 0.234737 & 0.178421 & 0.760090 \\
\hline ВOJ3-3B & 105.00 & 23.40 & 18.00 & 11.90 & 13.00 & 13.50 & 0.222857 & 0.171429 & 0.769231 \\
\hline BOJ3-4B & 105.80 & 24.95 & 18.25 & 11.35 & 10.00 & 13.50 & 0.235822 & 0.172495 & 0.731463 \\
\hline ВOJ3-5B & 111.20 & 24.00 & 17.70 & 9.40 & 10.00 & 14.00 & 0.215827 & 0.159173 & 0.737500 \\
\hline BOJ3-1Y & 111.20 & 25.40 & 18.50 & 8.00 & 8.00 & 14.00 & 0.228417 & 0.166367 & 0.728346 \\
\hline ВOj3-2Y & 79.10 & 20.90 & 15.35 & 10.00 & 8.50 & 11.00 & 0.264223 & 0.194058 & 0.734450 \\
\hline BOJ3-3Y & 114.00 & 26.50 & 18.90 & 10.00 & 9.00 & 12.50 & 0.232456 & 0.165789 & 0.713208 \\
\hline BOJ3-4Y & 81.30 & 21.10 & 14.90 & 8.40 & 9.50 & 12.25 & 0.259533 & 0.183272 & 0.706161 \\
\hline BOJ3-5Y & 80.80 & 21.80 & 15.10 & 8.90 & 11.00 & 12.00 & 0.269802 & 0.186881 & 0.692661 \\
\hline BOJ3-6B & 85.00 & 21.00 & 14.75 & 8.35 & 10.00 & 12.00 & 0.247059 & 0.173529 & 0.702381 \\
\hline
\end{tabular}


Table 4. The biometric measurements of Turritella simplex taken from CLN01-A.

\begin{tabular}{|c|c|c|c|c|c|c|c|c|c|}
\hline \multirow{2}{*}{$\begin{array}{c}\text { Code } \\
\text { Species }\end{array}$} & \multicolumn{9}{|c|}{ CLN01-A } \\
\hline & \multicolumn{9}{|c|}{ Turritella simplex } \\
\hline Location & \multicolumn{9}{|c|}{ S. Cilanang, Gn, Halu, Bandung } \\
\hline No. Spec & $\mathrm{L}_{(\mathrm{mm})}$ & $\mathrm{W}_{\text {ang }}$ & $\mathrm{W}_{\text {sut }}$ & $\mathrm{W}_{\mathrm{w} 5}$ & $\alpha\left({ }^{\circ}\right)$ & Whorl Number & $\mathrm{W}_{\text {ang }}: \mathrm{L}$ & $\mathrm{W}_{\text {sut }}: \mathrm{L}$ & $\mathrm{W}_{\text {sut }}: \mathrm{W}_{\text {ang }}$ \\
\hline 01A/1B & 40.40 & 15.00 & 10.95 & 5.90 & 21.00 & 9 & 0.371287 & 0.271040 & 0.730000 \\
\hline $01 \mathrm{~A} / 2 \mathrm{~B}$ & 41.80 & 16.30 & 11.80 & 7.00 & 21.00 & 9 & 0.389952 & 0.282297 & 0.723926 \\
\hline $01 \mathrm{~A} / 3 \mathrm{~B}$ & 30.55 & 14.95 & 10.30 & 6.50 & 21.00 & 8 & 0.489362 & 0.337152 & 0.688963 \\
\hline $01 \mathrm{~A} / 1 \mathrm{Y}$ & 50.25 & 14.40 & 11.20 & 5.50 & & 12 & 0.286567 & 0.222886 & 0.777778 \\
\hline $01 \mathrm{~A} / 2 \mathrm{Y}$ & 38.50 & 16.00 & 10.50 & 7.60 & & 8 & 0.415584 & 0.272727 & 0.656250 \\
\hline $01 \mathrm{~A} / 3 \mathrm{Y}$ & 53.80 & 17.60 & 12.00 & 7.00 & & 11 & 0.327138 & 0.223048 & 0.681818 \\
\hline $01 \mathrm{~A} / 4 \mathrm{Y}$ & 27.70 & 13.40 & 9.70 & 9.20 & & 8 & 0.483755 & 0.350181 & 0.723881 \\
\hline $01 \mathrm{~A} / 5 \mathrm{Y}$ & 37.80 & 13.70 & 11.00 & 6.70 & & 10 & 0.362434 & 0.291005 & 0.802920 \\
\hline $01 \mathrm{~A} / 6 \mathrm{Y}$ & 37.40 & 15.75 & 11.30 & 7.10 & & 10 & 0.421123 & 0.302139 & 0.717460 \\
\hline
\end{tabular}

Table 5. The biometric measurements of Turritella djadjariensis taken from Pasir Ipis (PsI01).

\begin{tabular}{|c|c|c|c|c|c|c|c|c|c|}
\hline Code & \multicolumn{9}{|l|}{ PsI01 } \\
\hline Species & \multicolumn{9}{|c|}{ Turritella djadjariensis } \\
\hline Location & \multicolumn{9}{|c|}{ Pasir Ipis, Cirebon } \\
\hline No. Spec & $\mathrm{L}_{(\mathrm{mm})}$ & $\mathrm{W}_{\text {ang }}$ & $\mathrm{W}_{\text {sut }}$ & $\mathrm{W}_{\mathrm{w} 8}$ & $\alpha\left(^{\circ}\right)$ & Whorl Number & $\mathrm{W}_{\text {ang }}: \mathrm{L}$ & $\mathrm{W}_{\text {sut }}: \mathrm{L}$ & $\mathrm{W}_{\text {sut }}: \mathrm{W}_{\text {ang }}$ \\
\hline $\mathrm{PI01/1Y}$ & 83.90 & 26.10 & 18.00 & 10.60 & & 14 & 0.3110846 & 0.2145411 & 0.6896552 \\
\hline $\mathrm{PI01/2Y}$ & 79.00 & 25.25 & 17.70 & 11.30 & & 13 & 0.3196203 & 0.2240506 & 0.7009901 \\
\hline PI01/3Y & 75.10 & 25.50 & 17.70 & 10.75 & & 13 & 0.3395473 & 0.2356858 & 0.6941176 \\
\hline PI01/4Y & 68.35 & 21.60 & 16.20 & 11.00 & & 12 & 0.3160205 & 0.2370154 & 0.75 \\
\hline PI01/5Y & 58.50 & 20.30 & 13.20 & 10.00 & & 11 & 0.3470085 & 0.225641 & 0.6502463 \\
\hline PI01/6Y & 64.80 & 21.00 & 15.10 & 10.00 & & 12 & 0.3240741 & 0.233025 & 0.7190476 \\
\hline $\mathrm{PI} 01 / 7 \mathrm{Y}$ & 69.70 & 24.00 & 16.35 & 10.70 & & 12 & 0.3443329 & 0.234577 & 0.68125 \\
\hline PI01/8Y & 58.00 & 19.70 & 13.15 & 10.00 & & 11 & 0.3396552 & 0.2267241 & 0.6675127 \\
\hline
\end{tabular}

Table 6. The biometric measurements of Turritella javana taken from Cijarian (CJR02B).

\begin{tabular}{|c|c|c|c|c|c|c|c|c|}
\hline Code & CJR02 & & & & & & & \\
\hline Species & Turritella & & & & & & & \\
\hline Location & S. Cijariar & an Ratu & & & & & & \\
\hline No. Spec & $\mathrm{L}_{(\mathrm{mm})}$ & $\mathrm{W}_{\text {ang }}$ & $\mathrm{W}_{\text {sut }}$ & $\alpha\left(^{\circ}\right)$ & Whorl Number & $\mathrm{W}_{\text {ang }}: \mathrm{L}$ & $\mathrm{W}_{\text {sut }}: \mathrm{L}$ & $\mathrm{W}_{\text {sut }}: \mathrm{W}_{\text {ang }}$ \\
\hline CJ02B-1B & 59.60 & 15.75 & 11.40 & 11.00 & 11.00 & 0.264262 & 0.191275 & 0.723810 \\
\hline CJ02B-2B & 56.85 & 12.60 & 9.20 & 12.00 & 12.00 & 0.221636 & 0.161829 & 0.730159 \\
\hline CJ02B-3B & 40.75 & 11.90 & 8.75 & 11.50 & 10.00 & 0.292025 & 0.214724 & 0.735294 \\
\hline CJ02B-4B & 39.65 & 10.75 & 7.55 & 12.50 & 10.00 & 0.271122 & 0.190416 & 0.702326 \\
\hline Cj02B-6B & 52.30 & 12.30 & 8.85 & 11.00 & 12.00 & 0.235182 & 0.169216 & 0.719512 \\
\hline CJ02B-7B & 56.60 & 14.60 & 10.55 & 11.50 & 9.00 & 0.257951 & 0.186396 & 0.722603 \\
\hline CJ02B-8B & 44.80 & 12.50 & 8.60 & 10.00 & 10.00 & 0.279018 & 0.191964 & 0.688000 \\
\hline
\end{tabular}


is based on the hypothesis that each additional the shell length will be followed by large changes in the last whorl. If this occurs, then each species may show a different pattern.

The results showed that MNT13 samples have a wide distribution, and the other samples showed a narrow distribution. Each species is forming an independent cluster, it is mean that each ratio of shell lenght with $\mathrm{W}_{\text {ang }}$ is correlated with a particular species.

Approaching with the cluster model, the data indicates the variability represented in 2 groups. Group A consists of CJR02B and CLN01A (small shell), Group B consists of Pasir Ipis, MNT13 and BOJ03 (large shells) (Figure 4).

\subsection{Ratio of Shell Length (L): $W_{\text {sut }}$}

This ratio is based on the shell length with the maximum width of suture at last whorl. This parameter has never been used to determine a species. Based on the nature turreted it could be estimated that each additional length of the shell will be followed by additional wide of the

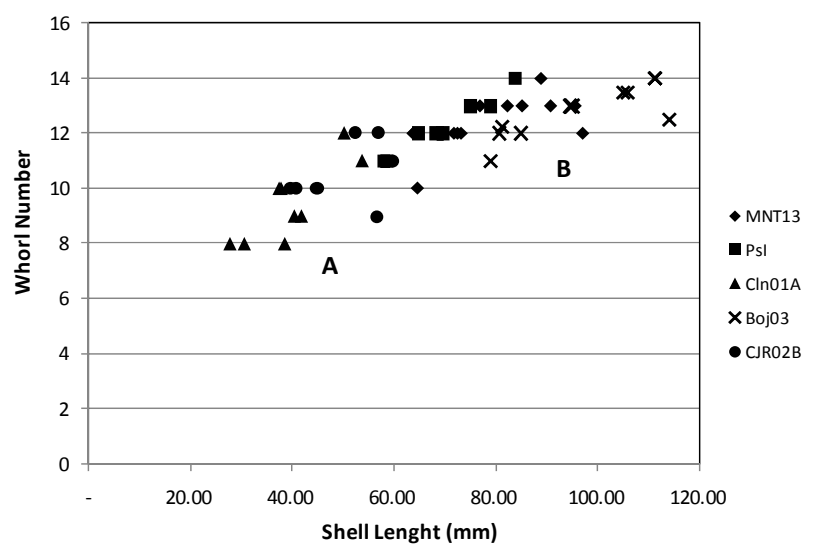

Figure 3. Distribution of ratio of shell length with whorl number, tend to be distributed.



Figure 4. Distribution of the ratio of shell length with a maximum width of the last whorl $\left(W_{\text {ang }}\right)$. suture at last whorl. If this occurs, different species should be show different patterns.

Specimens from MNT13 and PsI distributed on the same area, it's possible because they are from the same formation. Based on size of shell it can be divide into two groups (Figure 5). Group A consists of CJR02B, and CLN01A with short-sized shells. Group B consists of Pasir Ipis, BOJ03 and MNT13 with large shells.

\subsection{Ratio of $W_{\text {ang: }}: W_{\text {sut }}$}

This ratio is a comparison between the maximum width of last whorl with maximum wide of suture at last whorl. The nature of uniformity in the Family Turritellidae is a turreted form. Turreted form should be occured if the ratio between the suture whorl with a maximum width of the whorl is relatively consistent. The comparisons between one species and another will show a relatively equal ratio values.

The samples from MNT13 show a widened spread, while other samples show the opposite. This shows that the nature of the turreted can be seen in the ratio of $\mathrm{W}_{\text {ang }}: \mathrm{W}_{\text {sut }}$.

Approach taxa cluster analysis there are two large clusters. Cluster A consists of CJR02B and CLN01A, which is a cluster of small-sized taxa. Cluster B grouping BOJ03, PsI and MNT13, as large (Figure 6).

\section{Discussion and Synthesis}

Results of the parameters analysis show a consistent character in each population, so that each population can be synonyms as a distinct species. All parameters could be used to determinate a species.

Overall cluster analysis of all chart shows two large clusters of consistent groups (Figure 7). Based on geological especially at chronological studies (Table 1), two groups of clusters turned out to represent several things:

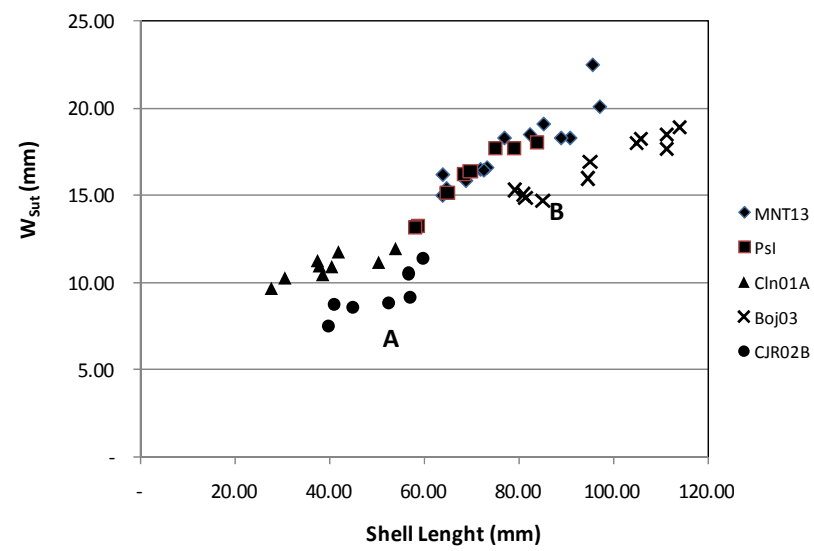

Figure 5. Distribution of ratio of shell length to width suture of the last whorl $\left(W_{\text {sut }}\right)$ Distribution points clustered into two groups: $A$ and $B$. 


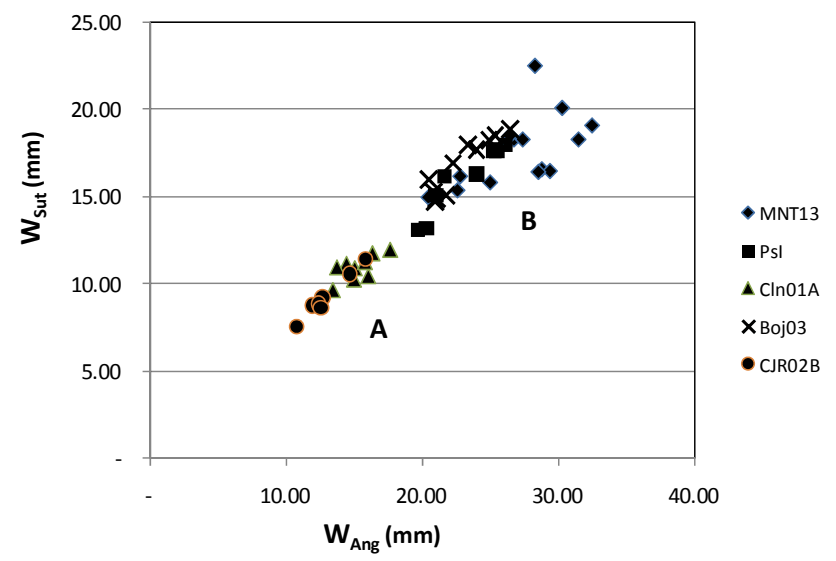

Figure 6. Distribution of ratio of the ratio of $W_{\text {ang }}$ with $W_{\text {sut }}$ distribution points clustered into two groups: $A$ and $B$.


Figure 7. Distribution of each ratio associated with chronological. A is representative sample from upper Miocene to Pliocene, $B$ is representative from Pliocene to Pleistocene.

1) Based on the aspects of stratigraphy, cluster A is representative group of Upper Miocene-Lower Pliocene. Cluster B is represents a group of Plio-Pleistocene.

2) Aspects of evolution shows that the trend toward the increas of body size at a younger age. It seens that the small size of cluster A realted to Upper Miocene-Lower Pliocene specemines. Whereas large-sized cluster B to younger specimens (Pliocene-Pleistocene).

\section{Conclusions}

This study shows biometrical aspects are reflection of geological condition. It has been seen that small size of individual appeared on Upper Miocene-Lower Pliocene, whereas large-sized ones appear in younger level Pliocene-Pleistocene in age.

Thus the emergence of larger Turritellidae fossils can 
be used to identify rocks from Pliocene to Pleistocene. While the small shells can be identify to older age of rocks. This research needs to be developed further, which is valid only in Java alone or also in other areas.

\section{Acknowledgements}

Special thanks for Dr. Tomoki Kase and Dr. Yukito Kurihara (National Museum of Nature and Science, Tokyo) whose helped sample collected during field works. Great thanks for Ministry of Education which give fund passing on doctoral research funding.

\section{REFERENCES}

[1] K. Martin, "Unsere Paleozoologische Kenntnis von Java, Mit Einleitende Bemerkungen Über die Geologi der Insel,” E. J. Brill, Leiden, 1919.

[2] C. H. Oostingh, "Mollusken als Gidsfossielen voor Het Neogeen in Nederlandsch-Indie," Handelingen van het Achste Nederlandsch-Indisch Natuurwetenschap-Pelijk Congres Gehouden te, Soerabaja van, 20-23 July 1938, pp. 508-516.

[3] H. M. Jenkins, "On Some Tertiary Mollusca fron Mount Sela, in the Island of Java. With a Description of a New Coral from the Same Locality, and a Note on the Scindian Fossil Corals. By P. Martin Duncan," Quarterly Journal of the Geological Society, Vol. 20, No. 77, 1863, pp. 45-74.

[4] M. Pozzobon, "Le Malacofaune Cenozoiche di Nanggulan e di Panggang Presso Yogyakarta (Giava, Indonesia) Inquadrate Nelle Fauna Della Tetide," Tesi di Laurea,
Dipartimento di Geologia, Paleontologia e Geofisica, Universita Degli Studi di Padova, 1997.

[5] Aswan, "Penggunaan Metode Biometri Dalam Menentukan Evolusi Fosil Moluska Turritella Dari Beberapa Tempat di P. Jawa \& Penerapannya Dalam Biostratigrafi," MS Thesis, Graduate Program, ITB, Bandung, 1997.

[6] T. Shuto, "Notes on Indonesian Tertiary and Quarternary Gastropods Mainly described by the Late professor K. Martin, I. Turritellidae and Mathildidae," Geology and Paleontology of Southeast Asia, Vol. XIV, 1974, pp. 135160.

[7] T. Kase, F. Kitao, Y. M. Aguilar, Y. Kurihara and H. Pandita, "Recontruction of Color Markings in Vicarya, a Miocene Potamidid Gastropod (Mollusca) from SE Asia and Japan," Paleontological Research, Vol. 12, No. 4, 2008, pp. 345-353. doi:10.2517/prpsj.12.345

[8] S. Martodjojo, "Evolusi Cekungan Bogor," Institut of Technology, Bandung, 2003.

[9] C. W. Merriam, "Fossils Turritellas from the Pacific Coast Region of N. America," University California Published Bulletin, Dept. of Science, Vol. 26, No. 1, 1941, pp. $1-214$.

[10] J. Marwick, "Generic Revision of the Turritellidae," Proceedings of the Malacological Society of London, Vol. 32, No. 4, 1957, pp. 144-166.

[11] T. Kotaka, "The Cenozoic Turritellidae of Japan," Science Reports of Tohoku University Series 2, Vol. 31, No. 2, 1959, pp. 1-135.

[12] T. Shuto, "Neogene Gastropods from Panay, the Philippines," Memoar Faculty of Science, Kyushu University, Series D, Vol. 19, No. 1, 1969, pp. 1-250. 